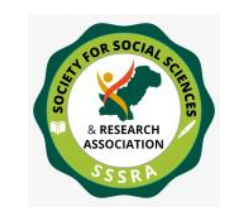

\title{
Socio-Economic Hurdles to Peacebuilding in Conflict Affected Areas of Pakistan: A Post Conflict Study of District Swat, Khyber Pakhtunkhwa
}

\author{
Mohammad Hussain \\ Lecturer and PhD Student, \\ Department of Sociology, \\ University of Malakand, Khyber Pakhtunkhwa, Pakistan \\ mohammadhussain.soc@uom.edu.pk \\ Prof. Dr. Arab Naz \\ Department of Sociology, \\ University of Malakand, Khyber Pakhtunkhwa, Pakistan \\ Arabnaz@yahoo.com
}

\begin{abstract}
It is relatively easy to stop conflict but difficult to achieve peace. Peace or peacebuilding is not merely to abate conflict rather it is an activity that aims to resolve the practices of injustice in peaceful ways and transform the socio-economic and structural conditions that cause conflicts. Societies in post conflict transitions pose the challenges of uncertainty and insecurity that are if not addressed properly with a holistic, and durable peacebuilding strategy can revert to violence and conflict. Most of these challenges are the result of social and economic imbalances that are deeply embedded in the societal structure and cultural setup which do not allow peacebuilding to be sustainable. This paper as part of PhD study aimed to investigate the factors as hurdles affecting peacebuilding in conflict affected areas of Khyber Pakhtunkhwa province of Pakistan in general and specifically district Swat. In this study, qualitative research methods especially grounded theory approach and theoretical sampling are used for identification of research participants, and the data is also collected through interviews and analysis. This study aims to find the social and economic hurdles that affect peacebuilding in the conflict affected areas of Khyber Pakhtunkhwa in general and specifically district Swat. The study shows that peacebuilding activities are suffered in target areas because of delay in justice, inadequate access of pubic to social
\end{abstract}




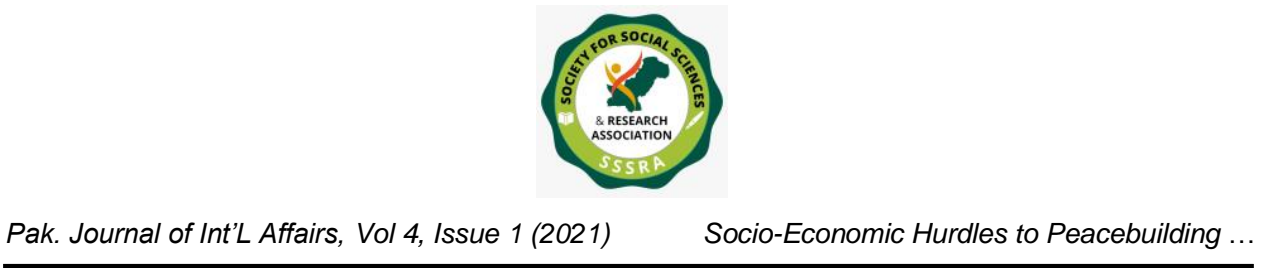

services, trust deficit, and incompatibility of peacebuilding to local culture. The provision of social services to people and making national institutions trustworthy can build durable peace in the society.

Keywords: Delay in Justice; Incompatible Peacebuilding; Inequitable Access of Public to Social Services; Militant Conflict; Trust Deficit.

\section{Background of the Study}

Human beings are peaceful and want to live in peace, on the other hand, conflicts occur in routine at every walk of humans' life and are unavoidable (Brahnam, Margavio, Hignite, Barrier, \& Chin, 2005; IQBAL, 2016). Conflict is a situation of disagreement which prevails at all levels, within and between individuals, communities, and countries. People of every background, class, age, gender, nationality, ethnicity, and race experience conflict in one way or another. Most of the conflicts that occurred after World War I, were intrastate rather than interstate. Similarly, most of the armed intrastate conflicts that occurred after World War II, have occurred either at regional or local level, and most of them occurred in developing countries (Seif, 2015). Some of the recent ethno-racial and religio-sectarian conflicts have deeply affected many countries such as Sudan, Sierra Leone, Vietnam, Korea, East Timor, El Salvador, Haiti, Somalia, Namibia, Mozambique, Cambodia, Bosnia, and Iraq around the world (Marshall \& Cole, 2008). Likewise, the violent activities of Tamil Tigers in Sri Lanka, brutality in Burma, and the terrorism in Afghanistan and Pakistan have negatively affected these countries (Gupta, 2020).

To deal with such violent conflicts, the states, local organizations and international community especially the United Nations make interventions to provide immediate relief and reconstruct the countries by devising peacebuilding strategies. (C. T. Call \& Cousens, 2008). Peacebuilding in this regard is the use of measures and initiatives to resolve the conflict by addressing its root causes and strengthen the capacities of national institutions to the levels accomplish multiple goals of people's grievances and stop the risk of relapsing into conflict (Cheng-Hopkins, 2016; Galtung, 2010; Office, 2010). It is used as strategy to reconstruct the destroyed socio-politico and economic fabric of conflict affected societies, transform the existing relationships and structures and construct a just environment for secure and peaceful life of humans (Lederach \& Appleby, 2010).

In this context, the contemporary peacebuilding is not merely a military intervention to focus on coercion, shooting or torturing, rather it is a joint and inclusive effort of civil 


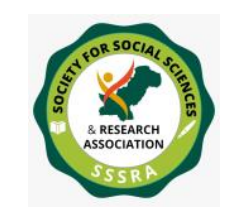

Socio-Economic Hurdles to Peacebuilding ...

society, military and international peacebuilding actors to help countries transform from conflict to peace and security (Paris, 2004). These days, peacebuilding as a persistent process is mostly characterized by the principles and values like political will, sincere and committed leadership, free and accountable government institutions and coherent state polices. It ensures timely delivery of public services, human rights protection, rule of law, building public trust, reconciliation, and community participation (De Coning, 2008; Fukuyama, 2014; Murphy, Pettis, \& Wray, 2016). Based on these principles, the focus of peacebuilding activities has been diverted from mere physical reconstruction and shortterm relief to the development of socio-economic and political aspects of post conflict societies (Donais, 2009).

However, the restoration of peace in post-conflict situations often becomes more complex because of the associated issues of security that mostly create challenges to peacebuilding processes (Haughton, 2002). In such situations, peacebuilding initiatives remain less effective because of the weaknesses both in national and local institutions to ensure human security and achieve durable peace (C. Call, 2004). Similarly, due to the issue of compatibility with local socio-cultural and politico-religious conditions (Khan, 2013), absence of political will and national commitment, and lack of coordination among different stakeholders many of these efforts fail to achieve their target goals (Paris, 2004). Resultantly, these issues further increase vulnerability of the societies and chances to relapse to conflict after the establishment of temporary peace (Bannon, 2010).

Pakistan is not exempted from the influence of both external and internal conflicts. In this country, many local conflicts and human rights violations have devastated many of its communities. However, this devastation surged with violent conflict in the form of terrorism specifically after 9/11 incident (Rabbi, 2012). Relatively, the Khyber Pakhtunkhwa province has been among the central targets of terrorists and been remained a rich ground for violent activities. With the influx of many militant groups into different parts of the province especially district Swat, the area suffered from a prolonged militant conflict and violence which still present the environment of insecurity and fragility. However, when the intensity of militancy decreased and controlled with the establishment of temporary peace, the government of Pakistan, civil society, and international community such as United Nations, World Bank, United Arab Emirates and United Nations Development Program started different peacebuilding activities to restore peace and reconstruct the affected areas.

Their initiatives include, physical and infrastructure development, arrangement of sports galas and festivals, peace melas, cultural shows, strengthening of institutions, arrangement of trainings for the employees and bringing relevant reforms in national and 


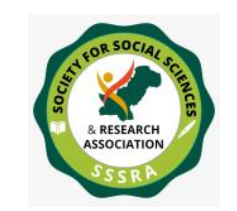

Socio-Economic Hurdles to Peacebuilding ...

local institutions. Though, these measures have benefited the area in terms of physical and infrastructure development, strengthening of police, judiciary and many other institutions and restoration of routine activities of people. However, the results of these efforts are not satisfactory overall, as they hardly address the root causes of conflict and violence, grievances of people and positively transform the socio-economic and political conditions of the society. These peacebuilding efforts do not achieve their target goals in the area because of different hurdles identified as major factors or concepts in this study that include injustice or delay in justice, inadequate access of public to social services, reluctance and trust deficit, and the issue of compatibility of peacebuilding with local culture which affect peacebuilding process. All these factors are developed through constant comparison of different categories and themes during data transcription, and accordingly analyzed with detailed discussion.

\section{The Argument}

At the end of prolonged militancy and subsequent military operations in different parts of Khyber Pakhtunkhwa province of Pakistan specifically district Swat, it has been projected that there is peace and normalcy at every walk of life. Peace in this context is seen as the militant conflict and associated violence has been stopped, and more than this, most of the destroyed and damaged infrastructure been reconstructed, and activities of routine been restored. All these have become possible through different peace, reconstruction and development initiatives being initiated by state, civil society and international peacebuilding agencies as mentioned earlier. Despite of these efforts, there is still uncertainty and public fear, people feel themselves insecure and observe the incidences of violence in routine. For instance, many heads and members of the peace committees and other influential persons have been attacked, kidnaped, and killed.

Though, the state has brought a considerable decrease in the intensity of violent activities - that of everyday killings and people's slaughtering, however, public insecurity and the cases of target killings still prevail as being reported by the local people which further push the area to a state of high vulnerability and resultantly increase the chances of relapsing to conflict. Similarly, the routine practice of injustice, economic inequality, violation of human rights and other forms of structural violence jeopardize the post conflict situation of the area and derail the ongoing peacebuilding process. While the state and other stakeholders have been engaged to address the mentioned issues and the associated challenges of uncertainty and insecurity in post conflict areas, but because of their security centered activities they are mostly failed to achieve the peace that is lasting and sustainable. 


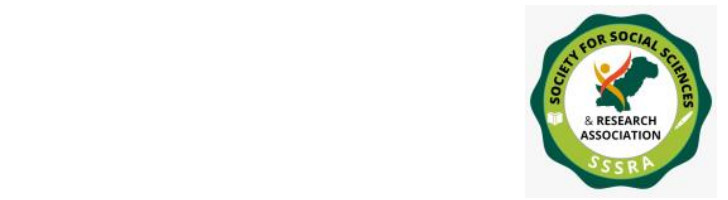

Pak. Journal of Int'L Affairs, Vol 4, Issue 1 (2021)

Socio-Economic Hurdles to Peacebuilding ...

\section{Methodology}

This paper as a part of $\mathrm{PhD}$ study is framed under qualitative research methodology. Grounded theory as a research strategy was used in this study which is mostly used by qualitative researchers including sociologists. In this strategy, researchers hardly rely on the existing literature and theories rather they derive the patterns and insights from field data (Mohajan, 2018). The target of this study was those areas of Khyber Pakhtunkhwa province of Pakistan that were affected by the waves of militancy and terrorism started after the incident of $9 / 11$. Though, terrorism and war against terrorism have affected many parts of this province but the militant activities remained more active in district Swat for a longer time. Since this district of the province suffered a lot in terms of suicide attacks, death toll, displacement of people and other destructions, therefore, this study was delimited to district Swat for data collection purpose.

Theoretical sampling technique was used in which sample size or number of participants is not predetermined and final, rather it requires some data to be collected and analyzed. It first identifies few cases as research participants purposively and then proceeds to identify others for the same purpose and continues until saturation in data occurs (Sbaraini, Carter, Evans, \& Blinkhorn, 2011). In this regard, this study purposively identified some segments of society as study units that include representative of different organizations, media and academia persons, government officers, members of civil society, political leaders, local elders as key informants, and common people as volunteers of peacebuilding activities. A total of 36 interviews and 04 Focused Group Discussions (FGDs) with the participants of mentioned study units were conducted. Further, interview method was used for data collection, where few of the interviews with the participants were conducted purposively while rest of the participants were identified and accessed through the network of friends and acquaintances. However, at the time of interviews, preference was given to those participants who were mostly residents of the area, who had either personal experience and understanding of the armed conflict and resultant peacebuilding efforts, or they remained in contact with others of the same experience. Similarly, the participants who were willing for participation in this study and could express their point of view on the phenomenon under study were interviewed.

In addition, interview guide with some open-ended questions was used to conduct indepth interviews. In this study, data collection and analysis were carried out parallel, based on the questions initially prepared, few interviews were conducted, transcribed, categories and themes were developed and then compared with the existing questions. The given questions were then modified and enriched with the addition of new concepts and then used for next interviews. In this way, the study followed a back-and-forth process of data collection, analysis, and comparison which continued till the last 


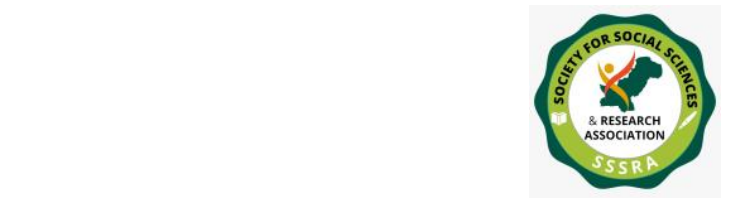

Pak. Journal of Int'L Affairs, Vol 4, Issue 1 (2021)

Socio-Economic Hurdles to Peacebuilding ...

interview. Similarly, all the factors as hurdles developed through constant comparison of different themes and categories were analyzed and discussed in detail.

\section{Results and Discussion}

\section{Injustice and Delay in Justice}

Countries in the stage of transition from armed conflict to peace face difficulty to decide how to deal with the reasons that caused violent conflict in the past and choose the choices that enhance their capacity to avoid the chances of conflicts in future (Connolly, 2012). Mostly, in such pre-conflict conditions or root causes of conflict, the issue of justice is severe which if not addressed properly give way to many other problems and affect the process of peacebuilding in post conflict societies (Francis, 2000; Moghalu, 2009). In this context, it was found that many areas of this study face the post conflict challenges and deal with the fragile socio-economic conditions and gross human rights abuses that are mostly linked to the pursuit of justice. Due to the practice of injustice and delay in justice most of the small-scale and petty disputes become armed conflicts at society level as mentioned by majority of this participants. People of the area want to resolve their routine disputes quickly as they were resolved at the time of Wali $^{1}$ Swat, and for this purpose they mostly approach to local courts. However, their filed petitions remain pending in courts for years and decades without any decision. This issue was in the notice of state authorities from a long time, but due to their less attention, it become severe before and after militant conflict. In field, majority of the participants mentioned in their interviews that these sorts of delaying tactics of the judiciary were the reasons of militancy and even still prevail as hurdles to the peacebuilding process in the area.

Since the state, civil society, and international community want to bring peace to the study areas by using different peacebuilding measures, in which provision of justice is one of the priorities and for this purpose they even bring reforms in the existing system of the judiciary. However, quick, and easy justice is not yet given to the deserving people except those who are influential in terms of power or money. These were the views of participants that they shared in interviews, in which one of the participants - a local elder and key informant stated that:

"Peace and justice are closely related. Peace of this area has always been affected by the suspended and unresolved disputes specifically related to land that people have from decades. The reported reforms in the existing justice system of the judiciary have not benefited the common people in true sense and eased the tiring process people get justice".

${ }^{1}$ Wali was the head of Swat state before its merger into Pakistan in 1969. 


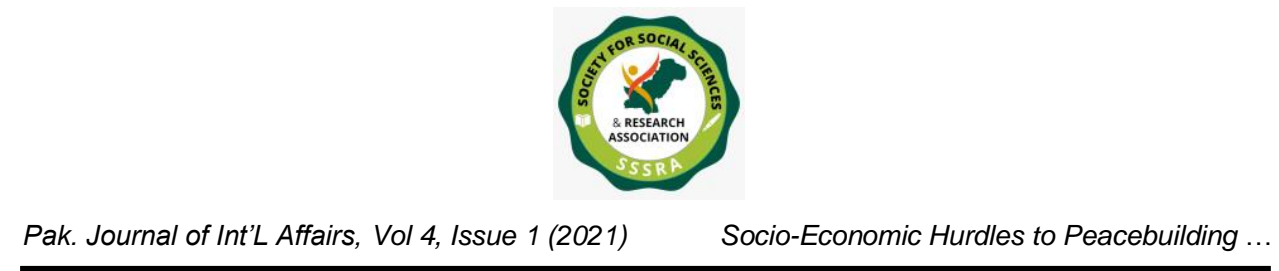

The study areas have always been faced problems from locals, the militants or Taliban are not totally outsiders rather many of them are recruited from the local communities who choose this profession as alternative means to bring out their frustration and get justice. When issues of the people are not resolved on time, they get disappointed from the role of judiciary and other institutions and choose illegal ways - that of criminality or militancy. In this way, they deviate from law of the state and challenge its writ. Besides, many people of the area are poor and cannot afford the expenses of the litigation as well as get fed up with the exploitative and torturing dealing of the judiciary personnel. The judges, lawyers, and representatives of the lawyers (Munshis) work as mafias who always create complications to the local and poor litigants. It was found that many of the people are passed from such troubling process of visiting the courts to get their disputes resolved. While sharing his experience, one of the participants and representative of a peacebuilding organization said that:

"The modern judiciary is one of the colonial mafias which complicates the process people get justice. I have been the victim of this dirty approach of judiciary and observe thousands other innocent people with the same experience. The victims are tortured for what they come while the offenders are protected and given safe heaven on earth. This kind of situation not only frustrate the people to choose violent ways for the satisfaction of their due need but complicate the peaceful life of others".

It was found that after the armed conflict, the area has been passed from many problems and people's perceived grievances that have not yet addressed by the concerned authorities and most of them are manipulated by the local elites for their socio-economic and political purposes that further increase the vulnerability and recurrence of violence and armed conflict. However, along with other problems, people face problems in accessing justice and protecting their rights that increase the risk people adopt violent means to resolve disputes and get their rights and ultimately affect the peacebuilding process.

The findings of this study converge to the results identified by the research studies of Cravo (2018), Moghalu (2009) and Francis (2000) that many of the reasons of conflicts such as discrimination, exploitation, marginalization, unequal provision of basic needs etc., are basically ignited by the absence of justice or weak rule of law. It is said that in many of the conflict-ridden countries there is lack of public confidence over the functions and approach of national justice system (Buescher, 2013). This weak justice system mostly prevails because of many factors including lack of trained and qualified prosecutors and their inappropriate behavior and dealing with local people that 


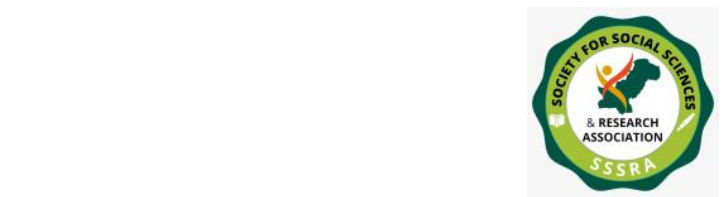

Pak. Journal of Int'L Affairs, Vol 4, Issue 1 (2021)

Socio-Economic Hurdles to Peacebuilding ...

perpetuates a culture of resolving disputes through violence. Similarly, in many of the countries the factors like injustice, human rights violations, inequality, unresolved land disputes and corruption lead to violent conflicts and social upheaval which negatively affect their peaceful environments. In such situations, international community and member states consider rule of law and justice as among the major elements of conflict prevention, conflict resolution and sustainable peacebuilding and the protection of human rights (Feinäugle, 2018; Hestermeyer, 2015).

\section{Inequitable Access of Public to Social Services}

Unequal access of public to social services causes conflict and creates instability while their provision foster social cohesion and build inclusive and peaceful societies (McCandless \& Rogan, 2013). There is a close relationship between conflict, security, and peace development, based on this, the conflict-ridden and fragile societies in which the local institutions are unable to provide equitable access of people to social and economic opportunities have more chances of violence and conflict relapse (Bank, 2011). In this regard, the development of peace is associated to state's responsibility to satisfy basic needs of people and ensure their equal access to social services. In this study it was found that in Pakistan, people do not have the facility of free or at least affordable education, health and job opportunities, and this issue is comparatively severe in the conflict affected areas of Khyber Pakhtunkhwa including district Swat. Here, a huge amount is spent on peacebuilding activities like construction of buildings, roads and arranging other related programs which have relatively less impact as they do not address root causes of violence and conflict. For instance, poverty and unemployment are the reasons that force the people for violence as pointed out by majority of this study participants. People especially the youngsters when complete their education do not find jobs, become frustrated and resultantly adopt illegal ways of employment for their survival. Thus, the very purpose of getting education becomes useless and is considered as wastage of time and money. In this context, one of the participants - a peacebuilding practitioner stated that:

"When the state does not protect rights of its citizens, the citizens will not fulfill their duties and responsibilities. Every year thousands of youngsters are graduated from different educational institutions of the country and abroad and then wander for jobs until they give bribes to the brokers or agents. These reasons mostly lead the people to frustration, violence and resultantly exacerbate peace of the area. Contrary to this, we see people in other parts of the world who have all these services of life and live in peace". 


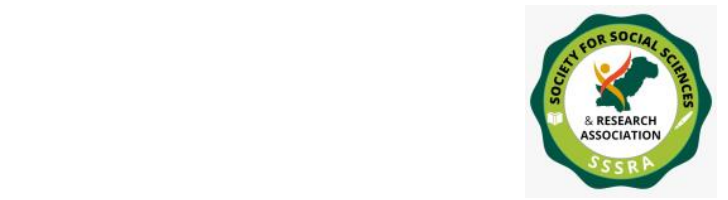

Pak. Journal of Int'L Affairs, Vol 4, Issue 1 (2021)

Socio-Economic Hurdles to Peacebuilding ...

Poverty as identified by majority of the participants was one of the reasons of Swat's conflict, and still because of poverty, many local disputes arise among people. Many poor people of the area live in the houses of Khans (rich and landlords) and because of their poor economic position they are often exploited at the hands of these Khans. The poor when find the opportunity take revenge from the local elites and khans to justify their exploitation. This factor was very dominant in the militant conflict of Swat as many of the local Taliban (militants) involved in the conflict were from these poor and exploited segments of the society. In the participants who linked this point with the disputes of past including the militancy and post conflict fragility, one - a university student said that:

"Peace can be brought to this society when people are given easy access to basic services. People of the area are poor and hardly fulfill their basic needs of life. They are peace lovers and do not like disputes but are pushed to violence because of their deprivation and exploitation".

In addition, health and education are basic needs of people, and when the fails to provide these needs to people in affordable way, they take all these by force as stated by a participant - local journalist. This use of force deteriorates peace of the area. In normal situation, people of the area are innocent and do not have negative intentions towards state and its institutions but when they are exploited, tortured, and manipulated, they become anti-social and go against the state and its institutions. In this context, one of the participants and member of the Dispute Resolution Council (DRC) said that 'many of our basic needs like food, shelter, recognition, identity and many more are hardly met'. He further pointed out 'we have the right of assembly, association, to get education, health, employment, and to express our views without the fear of external forces. If we people are deprived from these needs and rights, we get frustrated and go for conflict'. To majority of the participants many of these rights form the basis of 'human rights norms' which have already been documented in international documents of human rights and the denial of state to protect these rights prompt individuals or groups to use violent means to get their rights which mostly lead them to armed conflicts.

In relation to the findings of this study the facts that inequalities based on gender and age, as well as in the provision of justice, security, social services, and nationality lead the people to violence and conflict and create hurdles to peacebuilding and development in post conflict situations (Brinkman, Attree, \& Hezir, 2013). It is believed that in many of the conflict affected societies the state institutions and peacebuilding practitioners fail to provide jobs and services to the poor and unemployed people which provides an opportunity to different militant and extremist groups to easily recruit and give incentives to such an economically deprived section of the society (Del Castillo \& de Soto, 2017). 


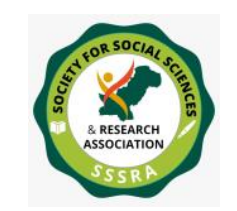

Pak. Journal of Int'L Affairs, Vol 4, Issue 1 (2021)

Socio-Economic Hurdles to Peacebuilding ...

In such situations the existing grievances of people - that of their exclusion from mainstream society, inequitable access to basic services and violation of their rights increase the chances of relapsing to conflict and affect the way they bring peace to the societies (Bank \& Nations, 2018).

\section{Reluctance and Trust Deficit}

The provision of basic and quality services to public reduces the trust deficit between state and public and builds enduring trust among different segments of the society. This type of trust development is believed as a prerequisite of peacebuilding in most of the post conflict situations (Wong, 2016). In case of this study, it was found that the militant conflict of Swat has affected the people socially, economically, and psychologically. The effects of this conflict still prevail that do not allow the locals to trust one another and especially the people who come from outside. In fact, there is fear and reluctance among peacebuilding practitioners as well as local people of the area who are benefited from peacebuilding programs. Local people are reluctant to accept the outsiders and share their views freely with them because of the negative experience they have got in the crises of Swat. People think that they were deceived by those whom they believed and trusted. These were the views and experiences of majority of the participants that they shared during interviews. Of these, one participant and an elder of the local community stated that:

"Local people of the area were trustworthy and cooperative with one another. However, the incidence of swat's crises changed their mindset. They are sure that they were deceived by their near and dears at the time of armed conflict, therefore now they are reluctant to say something openly in front of others even of their neighbors".

Similarly, the peacebuilding practitioners get reluctant when they go to the field for peacebuilding activities. They mostly encounter the communities which suffered from militancy and military operations and are still vulnerable to the attacks of militants who can easily target and harm these practitioners. This uncertainty hinders the peacebuilding efforts and development activities in the area. In this context, one of the peacebuilding practitioners shared his view as:

"In peacebuilding activities, we face difficulty to deal with the issue of public fear and hesitation. For instance, we have good speakers, and counsellors but all these experts cannot convey their ideas to these hesitant masses. We assure the masses as beneficiaries of peacebuilding for the secrecy of the information that they share with us. However, due 


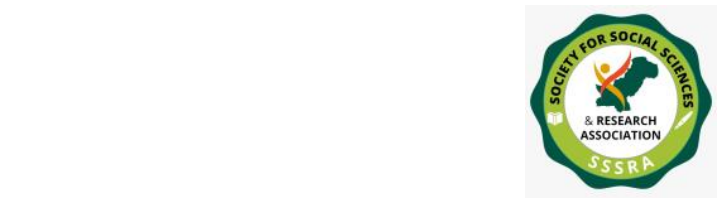

Pak. Journal of Int'L Affairs, Vol 4, Issue 1 (2021)

Socio-Economic Hurdles to Peacebuilding ...

to this public fear our staff members get cautious and try to avoid the discussion of very relevant points with people".

In addition, it was found that many of the peacebuilding organizations working in the area hardly benefit local people, as these kinds of projects are run by taking first the local elites and influential members in confidence. Where many of these elites are representatives of government who always think about their interest and hardly involve common people in such matters which further decreases the trust and satisfaction level of people on ongoing peacebuilding projects. It was reflected from the views of respondents in the field that most of the peacebuilding programs have always been benefited few - the elites, not all members of the communities which resultantly reduce the trust of public on peacebuilding actors and give way to recurrence of violence.

Like the findings of this study about trust deficit, it is believed that many of the peacebuilding organizations working in Muslim societies including Pakistan are perceived as agents of western colonization. These agents and their peacebuilding agenda are believed to undermine the traditional customs and structures and therefore hardly trusted by the local communities (Abu-Nimer \& Kadayifci, 2011). Along with other Muslim countries, it is argued that achieving a comprehensive and durable peace in different parts of Pakistan including district Swat becomes difficult due to lack of trust among different stakeholders involved in the peacebuilding process.

In this regard, local community is not convinced of the role of state institutions working for peacebuilding in Swat while same is the case with state institutions which are not satisfied from the role of civil society. Resultantly, this trust deficit creates a situation of misunderstanding and uncertainty in which the peacebuilding actors fail to achieve peace despite of their continuous struggles in the area (Shah, Nawab, \& Mehmood, 2020). Further, it is also evident that the issue of fear and trust on individuals level contribute to societal and political suspicion which mostly discourage the researchers to openly conduct field work in conflict sensitive environments and research populations to cooperate in the provision of information (Cohen \& Arieli, 2011).

\section{Incompatibility of Peacebuilding Agenda with Local Culture}

The modern peacebuilding approaches like liberal peacebuilding are widely criticized for being incompatible with local society and culture and are regarded as the tactics of hegemony and neo-colonialism (Piotrowska, 2015). Many of these approaches and efforts as externally imposed aspirations and values go against the local culture, where they overlook needs and capabilities of local populations and instead to address root causes of conflict perpetuate cycle of violence (Mac Ginty \& Richmond, 2013). In this context, 


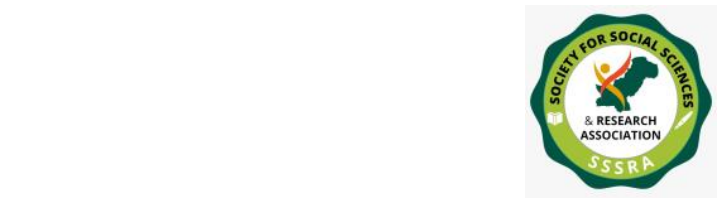

Socio-Economic Hurdles to Peacebuilding ...

Pakistan is one of the countries which suffers from the devastations of militancy and many of its communities including district Swat face difficulty to deal with the post conflict challenges and build durable peace. For this purpose, the country always struggles for external help and financial assistance to develop and transform its society. Working with these intentions, many of the researchers in Pakistan consciously or unconsciously project their society and its culture negatively to international donors of developed and western countries to get economic benefits.

It was found in the study area that many of the foreign researchers come here with a particular mind set and agenda, they study the society consisting of areas affected by militant conflict and military operations - that of Pakhtun society in Pakistan from distance and apply the findings of other societies over here. They forget the fact that there is difference between western and eastern societies and that the findings of one society cannot be applied to other society. However, resemblance to some extent can be made between distinct societies based on similar characteristics.

In this context, it was found from the views of participants in majority that peacebuilding programs carried out in the study areas are mostly western oriented which are less relevant to local culture and community and even come in clash to their norms and values. This clash is due to the difference in cultural traditions, and values. For instance, majority of the participants claimed that the western peacebuilding practitioners working in the society under study mostly use the liberal peacebuilding approach in which emphasis is given to women's freedom and participation, religious secularization, reforms in cultural traditions and values. However, despite of benefits, this sort of peacebuilding agenda creates complications in local culture because of the strict cultural values and restricted gender boundaries as pointed out by many of the peacebuilding practitioners and participants of this study. Of these, one participant stated that:

"Whenever the foreigners as donors of our peacebuilding and development projects come here, the first reservation they make is about lack of women's participation and the traditional practice of their purdah (veil). These foreigners think about our women in veils as like prisoners and consider we (the men) responsible for this type of practice which they think is against of women's rights".

Another participant and political representative shared his views regarding the incompatibility of ongoing peacebuilding programs to local culture:

"Many of the peacebuilding initiatives in post conflict Swat do not achieve the required objectives. Since the donors have the intension to increase women's participation in 


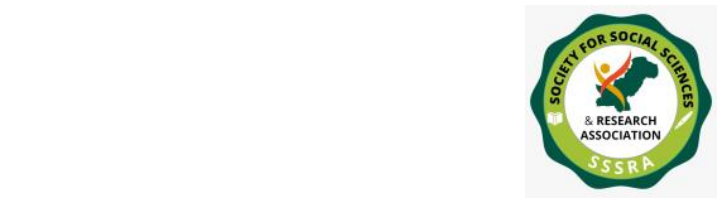

Socio-Economic Hurdles to Peacebuilding ...

public affairs, but the issue is that we - the local people do not agree with them on the points that come against our culture, ideology, values and religion".

In addition, the international community and donor countries bring different peacebuilding programs to the study areas to support the state institutions and local organizations. Apparently, they show their sincerity with people of these areas and their culture, but they also have their own interest and hidden agenda. In fact, they want to impose their hegemony, culture, and ideology over the people of Pakistan especially Pakhtuns who live in different parts of the country including Swat. Thus, their peacebuilding agenda have no compatibility to local culture and often lead the society towards confusion and chaos as mentioned by majority of the participants. Among the participants, a professor from academia said that:

"Most of the peacebuilding efforts do not address the actual problems of our people and hence go against our culture and values. Being a historian and native of the area, many people come to me from different parts of the country and abroad, they often ask that why we people are reluctant in case of our culture? I simply convince them with the argument that your culture and way of life is ok in your society and our culture and way of life is ok in our society. Mixing the cultures is like losing their purity and naturality. And we are not in this favor at least".

Besides, the field data revealed that the use of local peacebuilding strategies to make reconciliation between opponents and build durable peace in post conflict situations seem more appropriate and bring positive results. In this context, majority of the participants expressed that 'our culture is rich of disputes resolution mechanisms; it is our local tradition in Pakhtun culture to resolve disputes by mutual reconciliation and agreement of the two opposite parities and to satisfy needs and legitimate demands of both the victim and the offender in a peaceful way'. A participant - member of a local peace committee shared his view that 'we are in post conflict environment, we are not against the external or western methods of peacebuilding that are used by certain peacebuilding organizations, as they benefit us in different ways, but we do not accept methods that mostly contradict to our culture and values'. Further, it was found that the study areas are not in the position to manage peacebuilding initiatives independently without the help and support of western and external peacebuilders. This external support helps the local society to strengthen its institutions and enhance their resilient capacities. However, this support is temporary which despite of many short-term benefits creates long term dependency and if it is withdrawn after some time gives birth to many problems. In this regard, many of the international peacebuilding measures face the issue of compatibility 


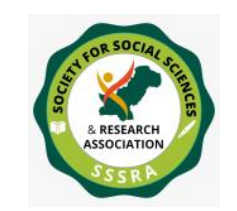

Pak. Journal of Int'L Affairs, Vol 4, Issue 1 (2021)

Socio-Economic Hurdles to Peacebuilding ...

to local community and culture as pointed out by majority of the participants of this study.

Likewise the findings of this study researchers like Piotrowska (2015), Benyera (2014) and Makoni (2010) argue that western and external methods of co-existence, conflict resolution, and peacebuilding do not give much importance to the underlying reasons of conflict, and lack the understanding of local dimensions and dynamics of culture. They believe that local approaches - community and culture based of conflict prevention, resolution and peacebuilding are more legitimate and credible as compare to the external ones. This dilemma has identified by different scholars and has duly reported by United Nations that local level disputes create hurdles to macro level international and national peacebuilding agenda (Nomikos, 2018). It means that the international peacebuilding activities face the issue of context relevancy and compatibility and hence do not achieve the desired goals particularly in post conflict fragile societies (Orakzai, 2011).

\section{Conclusion}

It is concluded from the above results and discussion that peacebuilding process becomes successful in a society where routine conflicts and disputes are resolved on time and people are provided the services of immediate justice and affordable education, health, employment, and other needs of life. Initiatives of peacebuilding in post conflict areas suffer from certain socio-economic factors that are embedded so deeply in the societal structure and cultural setup that merely the reconstruction of physical infrastructure and security centered interventions by the state and international community cannot make them successful and durable. In other words, the use of coercion by the state and its institutions work to ensure security, free the area from the influence of militants and normalize the situation after the armed conflict but investing little to address the root causes of conflict and the resultant environment of fragility and uncertainty create many challenges to post conflict peacebuilding. In this case, all these causative factors cover the premise of human security rather than national security. That is, bringing peace to the conflict affected societies without considering human security parameters - that if it is exclusive, incompatible to local culture and community, hardly emphasizes on justice and human rights provision, and not positively transforms individual and social relationships and strengthen institutions would not be durable and increases relapsing to conflict. 


\section{References}

Abu-Nimer, M., \& Kadayifci, A. (2011). Human rights and building peace: the case of Pakistani madrasas. The International Journal of Human Rights, 15(7), 11361159.

Bannon, I. (2010). The Role of the World Bank in Conflict and Development: An Evolving Agenda. Washington: Social Development Dept., Environmentally and Socially Sustainable Development Network.

Benyera, E. (2014). Exploring Zimbabwe's traditional transitional justice mechanisms. Journal of Social Sciences, 41(3), 335-344.

Brahnam, S. D., Margavio, T. M., Hignite, M. A., Barrier, T. B., \& Chin, J. M. (2005). A Gender-Based Categorization for Conflict Resolution. Journal of management development, 24(3), 197-208.

Brinkman, H.-J., Attree, L., \& Hezir, S. (2013). Addressing horizontal inequalities as drivers of conflict in the post-2015 development agenda. UN PBSO, Saferworld, Columbia, February: www. saferworld. org. uk/downloads/Inequalities-conflictFV. pdf.

Buescher, S. (2013). Conflict Prevention and Peacebuilding: Review of MDG-F Joint Programmes key findings and acievements. MDG Achivement Fund. Sustainable Development Goals and Funds. https://www.sdgfund.org/conflict-prevention-andpeace-building-review-mdg-f-joint-programmes-key-findings-and-achievements.

Call, C. (2004). The Problem of Peacebuilding: How UN Thinking has evolved in Recent years. Draft paper prepared for DPA, 27.

Call, C. T., \& Cousens, E. M. (2008). Ending wars and building peace: International responses to war-torn societies. International Studies Perspectives, 9(1), 1-21.

Cheng-Hopkins, J. (2016). Epilogue: The UN Peacebuilding Architecture-Good Intentions, Confused Expectations, Faulty Assumptions. In UN Peacebuilding Architecture (pp. 233-250). Routledge.

Cohen, N., \& Arieli, T. (2011). Field research in conflict environments: Methodological challenges and snowball sampling. Journal of Peace Research, 48(4), 423-435. 
Connolly, L. (2012). Justice and peacebuilding in post-conflict situations: An argument for including gender analysis in a new post-conflict model. ACCORD Occasional Paper, 6(1), 1-38.

Cravo, T. A. (2018). Post-conflict peacebuilding and the rule of law. In Handbook on the Rule of Law: Edward Elgar Publishing.

De Coning, C. (2008). The United Nations and The Comprehensive Approach: Danish Institute for International Studies (DIIS).

Del Castillo, G., \& de Soto, Á. (2017). Obstacles to Peacebuilding: Routledge.

Donais, T. (2009). Empowerment or Imposition? Dilemmas of Local Ownership in PostConflict Peacebuilding Processes. Peace \& Change, 34(1), 3-26.

Feinäugle, C. A. (2018). The Rule of Law and Its Application to the United Nations. In Handbook on the Rule of Law: Edward Elgar Publishing.

Francis, D. J. (2000). Torturous Path to Peace: The Lomé Accord and Postwar Peacebuilding in Sierra Leone. Security Dialogue, 31(3), 357-373.

Fukuyama, F. (2014). State-Building: Governance and World Order in the 21st century: Cornell University Press.

Galtung, J. (2010). Peace Studies and Conflict Resolution: The Need for Transdisciplinarity. Transcultural Psychiatry, 47(1), 20-32.

Gupta, D. K. (2020). Understanding Terrorism and Political Violence: The Life Cycle of Birth, Growth, Transformation, and Demise: Routledge.

Haughton, J. (2002). The Reconstruction of War-Torn Economies and Peace-Building Operations. Japan Bank for International Cooperation, Development Assistance Strategies in the, 21, 213-281.

Hestermeyer, H. P. (2015). A Rights-based Approach to the Rule of Law in International Law. The Rule of Law and Its Application to the United Nations (Nomos 2015, Forthcoming).

Iqbal, K. (2016). Role Of Education In The Social Conflicts Resolution And Peace Building At Secondary Level In Khyber Pakhtunkhwa. (Doctoral Dissertation, 
Northern

University,

Nowshera. http://prr.hec.gov.pk/jspui/bitstream/123456789/7865/1/Khalid\%20Iqbal\%20PhD $\% 20$ thesis.pdf.

Khan, K. (2013). Conflict, Livelihoods and Local Perspectives of Peace Building In post 9/11 Northwestern Pakistan: Dept. for International Development, UMB, Norway, $\mathrm{PhD}$ thesis.

Lederach, J. P., \& Appleby, R. S. (2010). Strategic Peacebuilding: An Overview. Strategies of Peace: Transforming Conflict in a Violent World, 19-44.

Mac Ginty, R., \& Richmond, O. P. (2013). The Local turn in Peace Building: A Critical Agenda for Peace. Third World Quarterly, 34(5), 763-783.

Makoni, M. (2010). African Life; Politics, Development and Social Life. SciDevNet.

Marshall, M. G., \& Cole, B. R. (2008). Global Report on Conflict, Governance and State Fragility 2008. Foreign Policy Bulletin, 18(1), 3-21.

McCandless, E., \& Rogan, J. (2013). Bringing peace closer to the people: The role of social services in peacebuilding. Journal of Peacebuilding \& Development.8 (3), $1-6$.

Moghalu, K. C. (2010). Prosecute or Pardon? Between Truth Commissions and War Crimes Trials. Peace versus justice? : The Dilemma of Transitional Justice in Africa. 69-95. Wood Bridge: Currey.

Mohajan, H. K. (2018). Qualitative research methodology in social sciences and related subjects. Journal of Economic Development, Environment and People, 7(1), 2348.

Murphy, K., Pettis, S., \& Wray, D. (2016). Building peace: The opportunities and limitations of educational interventions in countries with identity-based conflicts. Peace education: International perspectives, 35-50.

Nomikos, W. G. (2018). Local Peace, International Builders: How the UN Builds Peace from the Bottom Up. [Doctoral Dissertation], Yale University.

Office, U. P. S. (2010). UN Peacebuilding: An Orientation: United Nations New York. 
Socio-Economic Hurdles to Peacebuilding ...

Orakzai, S. B. (2011). Conflict in the Swat Valley of Pakistan: Pakhtun Culture and peacebuilding Theory-Practice Application. Journal of Peacebuilding \& Development, 6(1), 35-48.

Paris, R. (2004). At war's end: building peace after civil conflict: Cambridge University Press.

Piotrowska, D. (2015). The Value of Culture in Peacebuilding--Examples from Democratic Republic of Congo, Yemen and Nepal (Master's Thesis, City University, New York).

Rabbi, F. (2012). War against Terrorism and its Repercussions for Pakistan. Pakistan Journal of History and Culture, 33(2), 71-90.

Sbaraini, A., Carter, S. M., Evans, R. W., \& Blinkhorn, A. (2011). How to do a grounded theory study: a worked example of a study of dental practices. BMC medical research methodology, 11(1), 128.

Seif, M. S. (2015). Challenges and prospects of reconstruction and Peace building: case studies of Haiti, Cambodia and Mozambique (Doctoral Dissertation, University of Nairobi).

Shah, Q. A., Nawab, B., \& Mehmood, T. (2020). The Role of Stakeholders in Post Conflict Peacebuilding in Swat, Pakistan. Lex Localis-Journal of Local SelfGovernment, 18(1).

United Nations. (2018). What People Fight Over: Arenas of Contestation. In Pathways for Peace: Inclusive Approaches to Preventing Violent Conflict; 141-182. The World Bank

Wong, P.-H. (2016). How can political trust be built after civil wars? Evidence from post-conflict Sierra Leone. Journal of Peace Research, 53(6), 772-785.

World Bank. (2011). World Development Report 2011: Conflict, Security, and Development. The World Bank. 